\title{
Letter to a District Health Authority from the National Schizophrenia Fellowship
}

A member of the National Schizophrenia Fellowship appealed to me, while I was Chairman, for help for her schizophrenic son who appeared to be living in great neglect and squalor in 'the community'. As the case was a good illustration of the dreadful failure of 'community care' which so many of our members all over the country write in to us about, I forwarded a copy of the letter to the Minister for Health, and asked him to call for a report. This he readily did, and in due course the health authority reported.

The health authority's report not only glossed over the complaints made, but showed a complete failure to understand the central issue, which was the special needs of sufferers from chronic schizophrenia. I put this point back to the health authority as in the letter below (names have been changed to protect the identity of the parties). The Fellowship would be very glad to have the views of readers of the Bulletin on the points made.

NichOlas LiNES

To the Chairman

Blankshire District Health Authority Blank Town.

\section{Dear Chairman}

John Brown

In my letter of 20 October 1987 , thanking you for your letter of 2 October enclosing the Unit General Manager's report on the John Brown case, I referred to the severe trauma suffered by people like John Brown when they are parked out in the community, without the constant care they require. I also said that I was sending the report to NSF's local Manager.

I have now received two reports from our local Manager, I have heard further from Mrs Brown, and I have studied further the Unit General Manager's report of 29 September in the light of those communications. The picture which emerges is that the case is still most disturbing. The most disturbing feature is that, if I may say so with respect, the Health Authority does not distinguish sufficiently between the varying degrees of mental illness, between those afflicted with it who can be satisfactorily 'normalised' and then live more-or less-happily in a normal house in a normal street, and those who either can never live without constant professional or family support, or will only be able to do so after long care and rehabilitation; even then needing careful and unremitting support in the community from professional staff. John Brown is plainly one of the latter category.

When I wrote to the Minister for Health on 26 June about him, he was living in neglect and in conditions of indescribable vulnerability and squalor, at the mercy of thugs and sexual perverts and thieves who invaded his flat. There have been ups and downs since then, with improvements when his medication was changed, and when for a few weeks a skilful community psychiatric nurse was able to take a close interest until she left the case for further training. The basic position is still as unsatisfactory as when I wrote to the Minister; on 4 October John took a massive overdose in attempting suicide and had to be taken to hospital.

The Unit General Manager's report glossed over the complaints made by Mrs Brown. It referred to a nursing plan for John, and the support of the Continuing Care Team, and to "times of tension between her (Mrs Brown) and her son" as though they were at the root of John's problems. It asks why the sailors had not been reported to the naval authorities: what retribution from the sailors might that have precipitated? The report also made a point of the facts that firstly John had been admitted several times to hospital, and secondly that he had never needed to be there for longer than two months at any one time. The complaint is made that John did not attend the day centre; would the day centre have been able to cope with or help someone as intelligent, and difficult, as he is?

What is not clear is whether the nursing care plan was ever anything more than skeletal, or what positive action the Continuing Care Team has taken to improve his lot (and that of others like him). What, however, is clear is that the Unit General Manager does not seem to have taken on board the fact, of which those of us who have lived with chronic schizophrenia in the family are painfully aware, that however intelligent and frequently lucid people like John Brown are, whatever the "illusion of normality", they need constant care and support which they cannot receive if isolated in the terrifying loneliness of a flat or bed-sitter. Formerly they received the asylum afforded by the mental hospitals. While with modern medical practice most do not now need that kind of asylum, they most emphatically need, and are not getting, a suitable alternative regime to hospital. In this context, the number of times John has been admitted to hospital, and whether admission has been refused or not, are an irrelevance. Mrs Brown has written that "John is NOT capable of living on his own-he would need almost daily support but still be left feeling lonely and afraid". This judgement seems to be incontrovertible.

In a letter to me last year the Parliamentary Under Secretary for Health wrote "We have stressed that hospitals should not close until appropriate facilities and services have been built up first". Presumably that applied to rundown also. The services and facilities have not been built up, but the people who are not getting them are, nowadays, denied the asylum of hospital.

May I ask you to call for a further investigation of the current arrangements for the care and support of John Brown, with a view to improving them?

I am copying this letter to Lord Skelmersdale, to whom you copied the Unit General Manager's original report.

National Schizophrenia Fellowship

R. N. LiNes

78 Victoria Road, Surbiton, Surrey, KT6 4NS 